\title{
1-Methyl-3-(2-(sulfooxy)ethyl)-1H-imidazol-3-ium Chloride as a New and Green Ionic Liquid Catalyst for One-Pot Synthesis of Dihydropyrimidinones under Solvent-Free Condition
}

\author{
Sami Sajjadifar, Eshagh Rezaee Nezhad, and Ghasem Darvishi \\ Department of Chemistry, Payame Noor University, P.O. Box 19395-4697, Tehran, Iran \\ Correspondence should be addressed to Sami Sajjadifar; ss_sajjadifar@yahoo.com
}

Received 8 June 2012; Revised 11 September 2012; Accepted 15 September 2012

Academic Editor: Francisco José Hernández Fernández

Copyright (C) 2013 Sami Sajjadifar et al. This is an open access article distributed under the Creative Commons Attribution License, which permits unrestricted use, distribution, and reproduction in any medium, provided the original work is properly cited.

An efficient and simple method for the preparation of 1-methyl-3-(2-(sulfooxy)ethyl)-1H-imidazol-3-ium chloride $\{(\mathrm{MSEI}) \mathrm{Cl}\}$ as an acidic ionic liquid is described. One-pot multicomponent condensation of 1,3-dicarbonyl compounds, urea/thiourea and aldehydes at $80^{\circ} \mathrm{C}$ affords the corresponding compounds in high yields and in short reaction times by using (MSEI)Cl.

\section{Introduction}

First reported for multicomponent reaction involves a threecomponent, one-pot condensation of an aldehyde, $\alpha, \beta$ ketoester, and urea under strongly acidic conditions discovered by Biginelli in 1893 [10]. In the past few decades, interest in this reaction has increased dramatically since dihydropyrimidinones have a wide range of biological activities, acting as calcium channel antagonists, anti-hypertensive, anti-bacterial and anti-inflammatory agents, while also possessing cytotoxic activity [11-17]. In order to improve the efficiency of Biginelli reaction, a variety of catalysts have been reported which of them $\mathrm{H}_{4} \mathrm{PMo}_{11} \mathrm{VO}_{40}$, [18], Dowex$50 \mathrm{~W}$ [19], $\mathrm{H}_{3} \mathrm{PW}_{12} \mathrm{O}_{40} / \mathrm{SiO}_{2}$ [20], $\mathrm{MgBr}_{2}$ [21], polymersupported 4-aminoformoyldiphenylammonium triflate [22], $\mathrm{NaHSO}_{4} / \mathrm{SiO}_{2}$ [23], $\mathrm{FeCl}_{3}$ [24], $\mathrm{ZrCl}_{4}$ [25], $\mathrm{Cu}(\mathrm{OTf})_{2}$ [26], $\mathrm{Bi}(\mathrm{OTf})_{3}$ [27], yutterbium triflate [28], $\mathrm{NH}_{2} \mathrm{SO}_{3} \mathrm{H}$ [29], 12Molybdopho sphoric acid [30], natural HEU type zeolite [31], $\mathrm{Sr}(\mathrm{OTf})_{2}$ [32], covalently anchored sulfonic acid onto silica [33], $\mathrm{ZrOCl}_{2} \cdot 8 \mathrm{H}_{2} \mathrm{O}$ [34], silica triflate [35], $\mathrm{Fe}\left(\mathrm{HSO}_{4}\right)_{3}$ [36], TCICA [37], $\mathrm{PPh}_{3}$ [38], $\mathrm{CaF}_{2}$ [39], [bmim] $\mathrm{BF}_{4}$-immobilized $\mathrm{Cu}(\mathrm{II})$ acetylacetonate [40], [bmim] $\left[\mathrm{FeCl}_{4}\right]$ [7], ionic liquidsunder ultrasound irradiation [41], and melamine trisulfonic acid [42] are examples. Ionic liquids (ILs), which have been widely promoted as green solvents, are attracting much attention for applications in many fields of chemistry and industry due to their chemical and thermal stability, low vapor pressure, and high-ionic-conductivity properties. Over the last few years, ILs have been popularly used as solvents for organic synthesis, catalysis, and also been used as media for extraction processes $[43,44]$. But some of the mentioned methods encounter drawbacks such as the requiring expensive reagents, long reaction times, low yields of the products and tedious workup. The advantages of the present procedure are simplicity of operation, short reaction times, inexpensive reagents, green condition, and the high yields of products.

We synthesized the bronsted acidic ionic liquid 1-methyl3-(2-(sulfooxy)ethyl)-1H-imidazol-3-ium chloride [45] as an efficient and reusable catalyst for the synthesis of DHPMs derivatives.

\section{Experimental}

IR spectra of the compounds were obtained on a PerkinElmer spectrometer version 10.03 .06 using a $\mathrm{KBr}$ disk. The ${ }^{1} \mathrm{H}$ nuclear magnetic resonance $\left({ }^{1} \mathrm{H}\right.$ NMR) spectra were recorded on a Bruker AQS 400 Avance instrument at $400 \mathrm{MHz}$ in dimethyl sulfoxide (DMSO- $\mathrm{d}_{6}$ ) using tetramethylsilane as an internal standard. The progress of reaction was followed with thin-layer chromatography (TLC) using silica gel SILG/UV 254 and 365 plates. All the products are known compounds and were characterized by comparing the IR, ${ }^{1} \mathrm{H}$ NMR, and ${ }^{13} \mathrm{C}$ NMR spectroscopic data and their melting points with the literature values. 


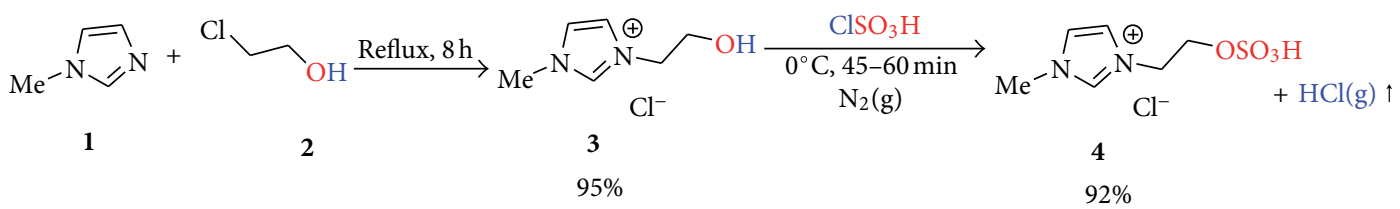

SCHEme 1: Synthesis of 1-methyl-3-(2-(sulfooxy)ethyl)-1H-imidazol-3-ium chloride.

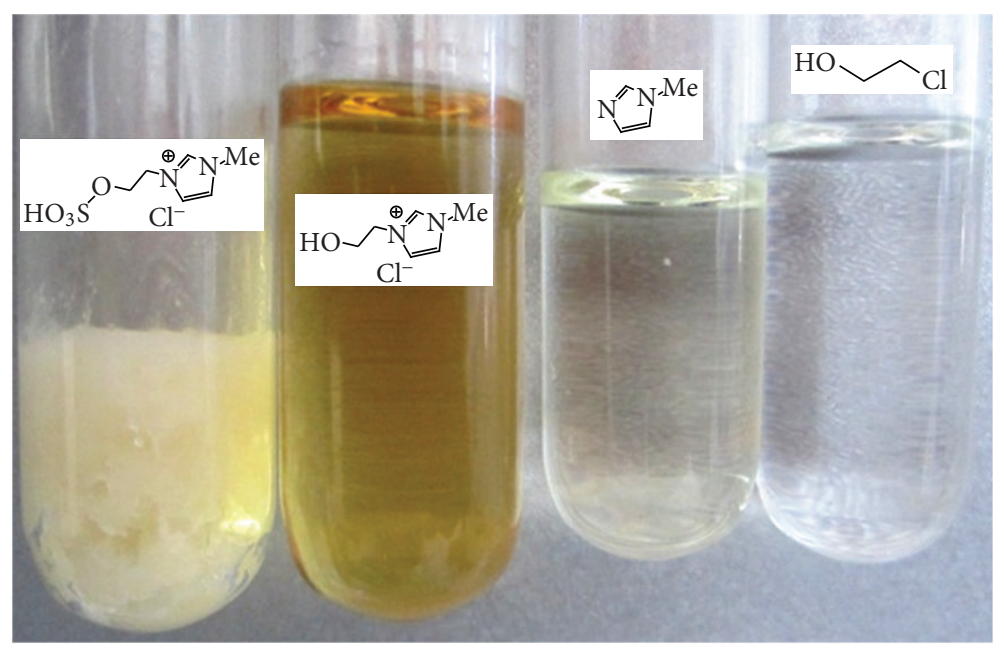

FIGURE 1

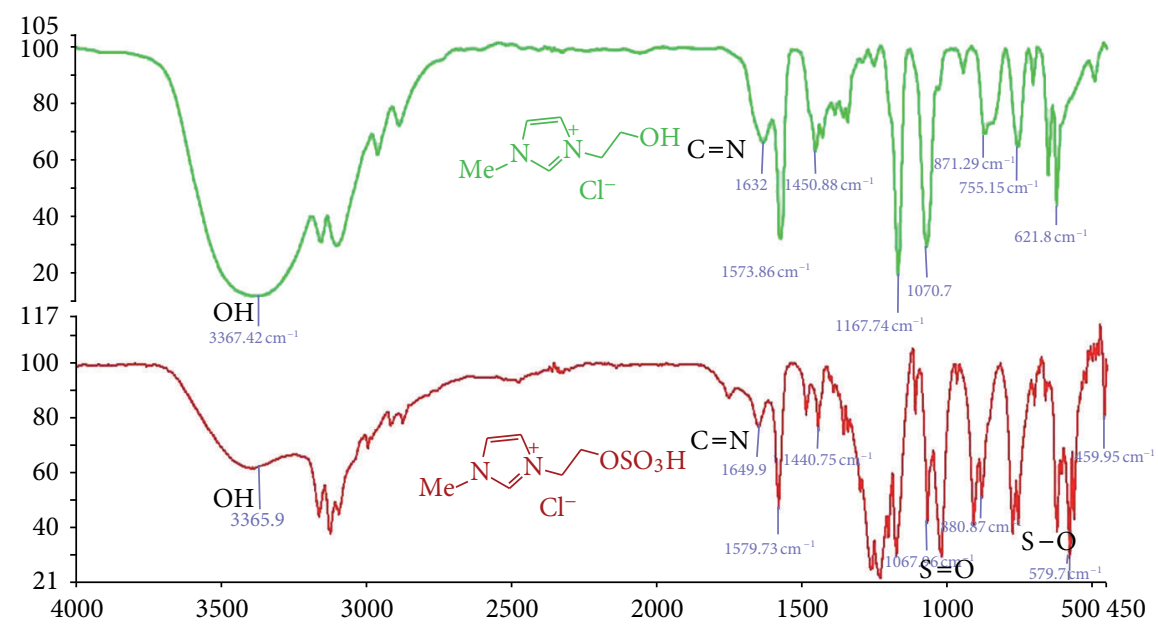

FIgURE 2: Comparison IR spectrum of ionic liquid 3, bronsted acidic ionic liquid 4.

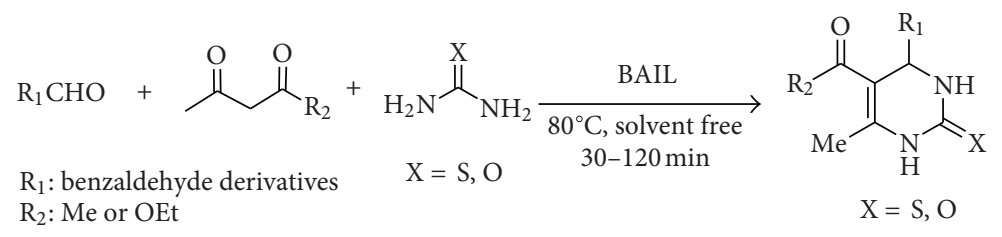

bronsted acidic ionic liquid 
TABLE 1: Temperature and time effect on dihydropyrimidinones synthesis.

\begin{tabular}{|c|c|c|c|}
\hline Entry & Temperature $\left({ }^{\circ} \mathrm{C}\right)$ & Time (min) & Yield (\%) \\
\hline 1 & r.t. & 90 & 36 \\
\hline 2 & 50 & 90 & 45 \\
\hline 3 & 80 & 30 & 93 \\
\hline 4 & 100 & 30 & 91 \\
\hline 5 & 120 & 30 & 90 \\
\hline
\end{tabular}

TABLE 2: Dihydropyrimidinones synthesis catalyzed by BrØnsted acidic ionic liquid (BAIL).

\begin{tabular}{|c|c|c|c|c|c|c|c|}
\hline \multirow{2}{*}{ Entry } & \multirow{2}{*}{$\mathrm{R}_{1}$} & \multirow{2}{*}{$\mathrm{R}_{2}$} & \multirow{2}{*}{$\mathrm{X}$} & \multirow{2}{*}{ Time (min) } & \multirow{2}{*}{ Yield (\%) } & \multicolumn{2}{|c|}{ M.p. $\left({ }^{\circ} \mathrm{C}\right)$} \\
\hline & & & & & & Found & Reported \\
\hline 1 & $\mathrm{Ph}$ & $\mathrm{Me}$ & $\mathrm{O}$ & 30 & 93 & $231-233$ & $235-236[1]$ \\
\hline 2 & $4-\mathrm{OH}-\mathrm{C}_{6} \mathrm{H}_{4}$ & $\mathrm{Me}$ & $\mathrm{O}$ & 30 & 95 & $254-256$ & $256-258$ [2] \\
\hline 3 & $4-\mathrm{Me}-\mathrm{C}_{6} \mathrm{H}_{4}$ & $\mathrm{Me}$ & $\mathrm{O}$ & 30 & 92 & $231-232$ & $228-229[1]$ \\
\hline 4 & $4-\mathrm{MeO}-\mathrm{C}_{6} \mathrm{H}_{4}$ & $\mathrm{Me}$ & $\mathrm{O}$ & 30 & 90 & $175-177$ & $177-179$ [2] \\
\hline 5 & $4-\mathrm{Cl}-\mathrm{C}_{6} \mathrm{H}_{4}$ & $\mathrm{Me}$ & $\mathrm{O}$ & 30 & 92 & $223-224$ & $224-226$ [3] \\
\hline 6 & $4-\mathrm{NO}_{2}-\mathrm{C}_{6} \mathrm{H}_{4}$ & $\mathrm{Me}$ & $\mathrm{O}$ & 45 & 85 & 227 (dec) & $229(\mathrm{dec})[2]$ \\
\hline 7 & $3-\mathrm{NO}_{2}-\mathrm{C}_{6} \mathrm{H}_{4}$ & $\mathrm{Me}$ & $\mathrm{O}$ & 45 & 82 & $246-248$ & $248-250[1]$ \\
\hline 8 & $\mathrm{Ph}$ & OEt & $\mathrm{O}$ & 45 & 88 & 203-205 & 201-202 [1] \\
\hline 9 & $2-\mathrm{OH}-\mathrm{C}_{6} \mathrm{H}_{4}$ & OEt & $\mathrm{O}$ & 45 & 92 & $200-202$ & 201-203 [3] \\
\hline 10 & $4-\mathrm{Me}-\mathrm{C}_{6} \mathrm{H}_{4}$ & OEt & $\mathrm{O}$ & 45 & 90 & $170-172$ & $170-171[1]$ \\
\hline 11 & $4-\mathrm{MeO}-\mathrm{C}_{6} \mathrm{H}_{4}$ & OEt & $\mathrm{O}$ & 45 & 87 & $198-200$ & 199-201 [4] \\
\hline 12 & 4- $\mathrm{Cl}-\mathrm{C}_{6} \mathrm{H}_{4}$ & OEt & $\mathrm{O}$ & 45 & 86 & $211-213$ & $209-210$ [1] \\
\hline 13 & $3-\mathrm{NO}_{2}-\mathrm{C}_{6} \mathrm{H}_{4}$ & OEt & $\mathrm{O}$ & 60 & 78 & $225-227$ & $226-227$ [4] \\
\hline 14 & $\mathrm{Ph}$ & $\mathrm{Me}$ & $S$ & 75 & 81 & $230-231$ & $232-233$ [5] \\
\hline 15 & $2-\mathrm{OH}-\mathrm{C}_{6} \mathrm{H}_{4}$ & $\mathrm{Me}$ & $\mathrm{S}$ & 75 & 83 & $239-241$ & $242-243$ [3] \\
\hline 16 & $4-\mathrm{Me}-\mathrm{C}_{6} \mathrm{H}_{4}$ & $\mathrm{Me}$ & $\mathrm{S}$ & 75 & 80 & $221-223$ & $222-224$ [5] \\
\hline 17 & $4-\mathrm{NO}_{2}-\mathrm{C}_{6} \mathrm{H}_{4}$ & $\mathrm{Me}$ & S & 90 & 73 & 106-107 & $108-110[6]$ \\
\hline 18 & $\mathrm{Ph}$ & OEt & $\mathrm{S}$ & 105 & 75 & 206-208 & 208-209 [5] \\
\hline 19 & $4-\mathrm{Me}-\mathrm{C}_{6} \mathrm{H}_{4}$ & OEt & $\mathrm{S}$ & 105 & 72 & 193-194 & 193-194 [1] \\
\hline 20 & $4-\mathrm{NO}_{2}-\mathrm{C}_{6} \mathrm{H}_{4}$ & OEt & $\mathrm{S}$ & 120 & 70 & $214-216$ & 209-212 [3] \\
\hline
\end{tabular}

TABLE 3: Comparison of catalytic ability of catalysts.

\begin{tabular}{|c|c|c|c|}
\hline Entry & Catalyst & Time (min) condition & Yield (\%) (reference) \\
\hline \multirow{2}{*}{1} & \multirow{2}{*}[\mathrm{BMIM}]{$\mathrm{FeCl}_{4}$} & 120 & 90 \\
\hline & & $90^{\circ} \mathrm{C}$, s.f. ${ }^{\mathrm{a}}$ & [7] \\
\hline \multirow{2}{*}{2} & \multirow{2}{*}{ [HMIM]Tfa } & 45 & 90 \\
\hline & & $50^{\circ} \mathrm{C}$, s.f. & {$[4]$} \\
\hline \multirow{2}{*}{3} & \multirow{2}{*}[\mathrm{BMIM}]{$\mathrm{BF}_{4}$} & 30 & 99 \\
\hline & & $100^{\circ} \mathrm{C}$, s.f. & [8] \\
\hline \multirow{2}{*}{4} & \multirow{2}{*}[\mathrm{HMIM}]{$\mathrm{HSO}_{4}$} & 90 & 96 \\
\hline & & $80^{\circ} \mathrm{C}$, s.f. & [9] \\
\hline \multirow{2}{*}{5} & \multirow{2}{*}{ [MSEI]Cl } & 30 & 93 \\
\hline & & $80^{\circ} \mathrm{C}$, s.f. & - \\
\hline
\end{tabular}

${ }_{\text {s.f.: solvent free condition. }}$ 


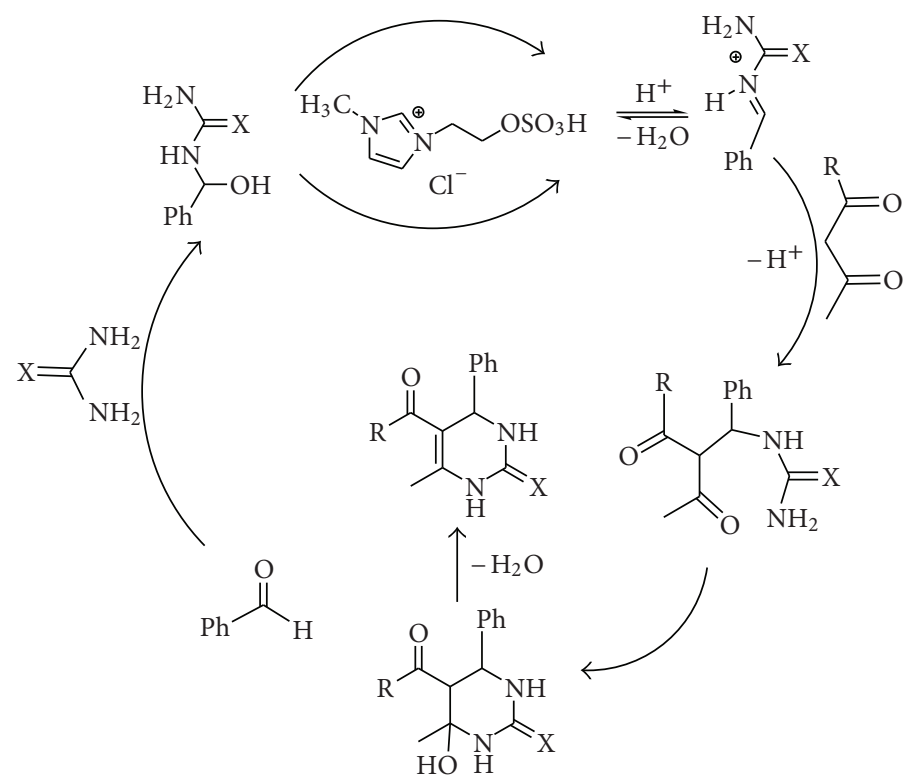

SCHEME 3: Mechanism of synthesis of 3,4-dihydropyrimidin-2(1H)-ones and -thiones.

TABLE 4: Formation of DHMP in different solvents and comparison with solvent-free condition.

\begin{tabular}{|c|c|c|c|c|}
\hline Entry & Solvent & Time (h) & Temperature $\left({ }^{\circ} \mathrm{C}\right)$ & Yield (\%) \\
\hline 1 & Ethanol & 4 & Refluxing & 81 \\
\hline 2 & $\mathrm{H}_{2} \mathrm{O}$ & 4 & Refluxing & $<20$ \\
\hline 3 & $\mathrm{MeCN}$ & 4 & Refluxing & 70 \\
\hline 4 & $\mathrm{CH}_{2} \mathrm{Cl}_{2}$ & 8 & Refluxing & 38 \\
\hline 5 & Solvent-free & 0.5 & 80 & 93 \\
\hline
\end{tabular}

TABLE 5: Recovery of catalyst.

\begin{tabular}{lcc}
\hline Number & Reaction & Yield (\%) \\
\hline 1 & First & 91 \\
2 & Second & 91 \\
3 & Third & 90 \\
4 & Forth & 88 \\
\hline
\end{tabular}

2.1. Preparation of Bronsted Acidic Ionic Liquid. 1-Methylimidazole 1 (4.1 g, $50 \mathrm{mmol}$ ) and 2-chloroethanol 2 (4.02 g, $50 \mathrm{mmol}$ ) were added in a flask containing $10 \mathrm{~mL}$ of $\mathrm{CHCl}_{3}$, and the mixture was refluxed for $8 \mathrm{~h}$ and removed $\mathrm{CHCl}_{3}$ under vacuum. Unreacted 1-methylimidazole or 2chloroehanol was extracted with ether $(3 \times 10 \mathrm{~mL})$ to give 1-methyl-3-(2-hydroxylethyl) imidazolium chloride (yield $95 \%)$. IR spectrum of compound 3: $\mathrm{OH}\left(3200-3600 \mathrm{~cm}^{-1}\right)$, $\mathrm{C}=\mathrm{C}\left(1450,1575 \mathrm{~cm}^{-1}\right)$, and $\mathrm{C}=\mathrm{N}\left(1643 \mathrm{~cm}^{-1}\right)$ (Figure 2).

A stoichiometric amount of $97 \%$ chlorosulfonic acid $(3.4 \mathrm{~mL}, 50 \mathrm{mmol})$ in $\mathrm{CCl}_{4}(10 \mathrm{~mL})$ was added dropwise to compound 3 over a period of $45-60 \mathrm{~min}$ at $0^{\circ} \mathrm{C}$, and $\mathrm{HCl}$ gas was evolved in an alkali trap immediately (Scheme 1). The mixture was washed with $\mathrm{CCl}_{4}(3 \times 10 \mathrm{~mL})$ to remove the unreacted chlorosulfonic acid (yield 92\%). IR spectrum of compound 4: $\mathrm{OH}\left(3200-3600 \mathrm{~cm}^{-1}\right), \mathrm{C}=\mathrm{C}(1440$, $\left.1579 \mathrm{~cm}^{-1}\right), \mathrm{C}=\mathrm{N}\left(1648 \mathrm{~cm}^{-1}\right), \mathrm{S}=\mathrm{O}\left(1019 \mathrm{~cm}^{-1}\right)$, and $\mathrm{S}-\mathrm{O}$ $\left(623 \mathrm{~cm}^{-1}\right)$ (Figures 1 and 2) [44].

2.2. General Procedure for the Preparation of DHPMs. A mixture of an aromatic aldehyde $(1 \mathrm{mmol}), \beta$-dicarbonyl ( $1 \mathrm{mmol})$, urea/thiourea $(1.5 \mathrm{mmol})$, and catalyst $(50 \mathrm{mg})$ was finely mixed together in a test tube at $80^{\circ} \mathrm{C}$ for the times reported in (Table 2). During the reaction process, a solid product spontaneously formed. The completion of the reaction was monitored by TLC. The reaction mixture was cooled to room temperature and then cold water $(20 \mathrm{~mL})$ was added to the reaction mixture and stirred for $10-15 \mathrm{~min}$. During this time, crystals of the product formed which were collected by filtration and dried and then recrystallized 
from ethanol to afford the pure product. The results are summarized in Table 2. The aqueous layer (including BAIL) was separated, and its solvent was evaporated to obtain pure BAIL. The recycled catalyst was used for the next run under identical reaction conditions.

\section{Results and Discussion}

The one-pot synthesis of 3,4-dihydropyrimidin-2(1H)-ones and -thiones was achieved by the three-component condensation of aldehydes, dicarbonyl, and urea or thiourea in presence of bronsted acidic ionic liquid is conducted at $80^{\circ} \mathrm{C}$, and the results are summarized in Table 1. The procedure gives products in good yields, short reaction times and avoids the use of organic solvents (handling, cost, safety, pollution) (Table 4). Environmental friendly ionic liquid afforded a valuable alternative to promote a numerous efficient catalytic systems that have already been proposed for the achievement of DHPMs. As long as, the reaction rate and the yields are depending on electron donating/withdrawing effect of the groups on the benzene ring in benzaldehydes. Aryl aldehydes containing electron-donating substituent gave excellent yields of the products in a shorter reaction time. The mechanism of the Biginelli reaction established by Kappe [6] proposed that the key step in this cyclocondensation process should involve the formation of $\mathrm{N}$-acyliminium ion intermediate (Scheme 3).

According at Table 2 the using of thiourea and ethylacetoacetate increased reaction time, and also the using of thiourea reduces the efficiency of Biginelli reaction. Thiourea stability of negatively charged than urea and low nucleophiles property of thiourea than urea at intermediate State. The catalyst is reusable and can be applied several times without any decrease in the yield of the reaction. As it can be seen from Table 3, (MSEI)Cl as a catalyst afforded the good results with respect to the another ionic liquid catalysts.

\section{Conclusions}

In summary, we have developed the use of bronsted acidic ionic liquid 1-methyl-3-(2-(sulfooxy)ethyl)-1H-imidazol-3ium chloride as an inexpensive, easy to handle, noncorrosive and environmentally benign catalyst for the Biginelli reaction from an aldehyde, a $\beta$-dicarbonyl, and urea or thiourea. The advantages of the present procedure are simplicity of operation, very short reaction times compared with other procedures for the preparation of dihydropyrimidinones derivatives, and the high yields of products. In this reaction the catalyst can be were easily recyclable after removing starting materials and water (Table 5).

\section{Acknowledgments}

The authors gratefully acknowledge partial support of this work by Payame Noor University (PNU) of Ilam.

\section{References}

[1] X. Jing, Z. Li, X. Pan, Y. Shi, and C. Yan, "NaIO ${ }_{4}$-catalyzed onepot synthesis of dihydropyrimidinones at room temperature under solvent-free conditions," Journal of the Iranian Chemical Society, vol. 6, no. 3, pp. 514-518, 2009.

[2] M. Dabiri, P. Salehi, M. Baghbanzadeh et al., "Efficient and eco-friendly synthesis of dihydropyrimidinones, bis(indolyl) methanes, and $\mathrm{N}$-alkyl and $\mathrm{N}$-arylimides in ionic liquids," Journal of the Iranian Chemical Society, vol. 4, no. 4, pp. 393-401, 2007.

[3] R. Zheng, X. Wang, H. Xu, and J. Du, "Brønsted acidic ionic liquid: An efficient and reusable catalyst for the synthesis of 3,4dihydropyrimidin-2(1H)-ones," Synthetic Communications, vol. 36, p. 1503, 2006.

[4] S. Ghassamipour and A. R. Sardarian, "One-Pot synthesis of dihydropyrimidinones by dodecylphosphonic acid as solid Bronsted Acid Catalyst under Solvent-Free Conditions via Biginelli condensation," Journal of the Iranian Chemical Society, vol. 7, no. 1, pp. 237-242, 2010.

[5] S. Besoluk, M. Kucukislamoglu, M. Nebioglu, M. Zengin, and M. Arslan, "Solvent-free synthesis of dihydropyrimidinones catalyzed by alumina sulfuric acid at room temperature," Journal of the Iranian Chemical Society, vol. 5, no. 1, pp. 62-66, 2008.

[6] H. W. Zhan, J. X. Wang, and X. T. Wang, "Solvent- and catalystfree synthesis of dihydropyrimidinthiones in one-pot under focused microwave irradiation conditions," Chinese Chemical Letters, vol. 19, no. 10, pp. 1183-1185, 2008.

[7] X. Chen and Y. Peng, "Chloroferrate(III) ionic liquid: efficient and recyclable catalyst for solvent-free synthesis of 3,4dihydropyrimidin-2(1H)-ones," Catalysis Letters, vol. 122, no. 3-4, pp. 310-313, 2008.

[8] J. Peng and Y. Deng, "Ionic liquids catalyzed Biginelli reaction under solvent-free conditions," Tetrahedron Letters, vol. 42, no. 34, pp. 5917-5919, 2001.

[9] Garima, V. P. Srivastava, and L. D. S. Yadav, "Biginelli reaction starting directly from alcohols," Tetrahedron Letters, vol. 51, no. 49, pp. 6436-6438, 2010.

[10] P. Biginelli, "Derivati aldeiduredici degli eteri acetile dossalacetico," Gazzetta Chimica Italiana, vol. 23, pp. 360-413, 1893.

[11] C. Oliver Kappe, W. M. F. Fabian, and M. A. Semones, "Conformational analysis of 4-aryl-dihydropyrimidine calcium channel modulators. A comparison of ab initio, semiempirical and X-ray crystallographic studies," Tetrahedron, vol. 53, no. 8, pp. 2803-2816, 1997.

[12] C. O. Kappe, "100 years of the Biginelli dihydropyrimidine synthesis," Tetrahedron, vol. 49, no. 32, pp. 6937-6963, 1993.

[13] K. S. Atwal, G. C. Rovnyak, B. C. O’Reilly, and J. Schwartz, "Substituted 1,4-dihydropyrimidines. 3. Synthesis of selectively functionalized 2-hetero-1,4-dihydropyrimidines," Journal of Organic Chemistry, vol. 54, no. 25, pp. 5898-5907, 1989.

[14] M. M. Amini, A. Shaabani, and A. Bazgir, "Tangstophosphoric acid $\left(\mathrm{H}_{3} \mathrm{PW}_{12} \mathrm{O}_{40}\right)$ : an efficient and eco-friendly catalyst for the one-pot synthesis of dihydropyrimidin-2(1H)-ones," Catalysis Communications, vol. 7, no. 11, pp. 843-847, 2006.

[15] B. Jauk, T. Pernat, and C. O. Kappe, "Design and synthesis of a conformationally rigid mimic of the dihydropyrimidine calcium channel modulator SQ 32,926," Molecules, vol. 5, no. 3, pp. 227-239, 2000.

[16] J. Azizian, M. K. Mohammadi, O. Firuzi, B. Mirza, and R. Miri, "Microwave-assisted solvent-free synthesis of 
bis(dihydropyrimidinone) benzenes and evaluation of their cytotoxic activity: research article," Chemical Biology and Drug Design, vol. 75, no. 4, pp. 375-380, 2010.

[17] M. B. Deshmukh, S. M. Salunkhe, D. R. Patil, and P. V. Anbhule, "A novel and efficient one step synthesis of 2-amino-5-cyano6-hydroxy-4-aryl pyrimidines and their anti-bacterial activity," European Journal of Medicinal Chemistry, vol. 44, no. 6, pp. 2651-2654, 2009.

[18] S. P. Maradur and G. S. Gokavi, "Heteropoly acid catalyzed synthesis of 3,4-dihydropyrimidin-2(1H)-ones," Catalysis Communications, vol. 8, no. 3, pp. 279-284, 2007.

[19] K. Singh, D. Arora, and S. Singh, "Dowex-promoted general synthesis of $\mathrm{N}, \mathrm{N}^{\prime}$-disubstituted-4-aryl-3,4-dihydropyrimidinones using a solvent-free Biginelli condensation protocol," Tetrahedron Letters, vol. 47, no. 25, pp. 4205-4207, 2006.

[20] E. Rafiee and F. Shahbazi, "One-pot synthesis of dihydropyrimidones using silica-supported heteropoly acid as an efficient and reusable catalyst: improved protocol conditions for the Biginelli reaction," Journal of Molecular Catalysis A, vol. 250, no. 1-2, pp. 57-61, 2006.

[21] H. Salehi and Q. X. Guo, "A facile and efficient one-pot synthesis of dihydropyrimidinones catalyzed by magnesium bromide under solvent-free conditions," Synthetic Communications, vol. 34, no. 1, pp. 171-179, 2004.

[22] M. Lei, D. D. Wu, H. G. Wei, and Y. Wang, "Polymer-supported 4-aminoformoyldiphenylammonium triflate (PS-AFDPAT): an effective and recyclable catalyst for the Biginelli reaction," Synthetic Communications, vol. 39, no. 3, pp. 475-483, 2009.

[23] M. A. Chari and K. Syamasundar, "Silicagel supported sodium hydrogensulfate as a heterogenous catalyst for high yield synthesis of 3,4-dihydropyrimidin-2 (1H)-ones," Journal of Molecular Catalysis A, vol. 221, no. 1-2, pp. 137-139, 2004.

[24] J. Lu and Y. Bai, "Catalysis of the Biginelli reaction by ferric and nickel chloride hexahydrates. One-pot synthesis of 3,4dihydropyrimidin-2(1H)-ones," Synthesis, vol. 4, pp. 466-470, 2002.

[25] C. V. Reddy, M. Mahesh, P. V. K. Raju, T. R. Babu, and V. V. N. Reddy, "Zirconium(IV) chloride catalyzed one-pot synthesis of 3,4-dihydropyrimidin-2(1H)-ones," Tetrahedron Letters, vol. 43, no. 14, pp. 2657-2659, 2002.

[26] A. S. Paraskar, G. K. Dewkar, and A. Sudalai, "Cu(OTf) $)_{2}$ : a reusable catalyst for high-yield synthesis of 3,4dihydropyrimidin-2(1H)-ones," Tetrahedron Letters, vol. 44, no. 16, pp. 3305-3308, 2003.

[27] R. Varala, M. M. Alam, and S. R. Adapa, "Bismuth triflate catalyzed one-pot synthesis of 3,4-dihydropyrimidin-2 $(1 H)$ ones: an improved protocol for the Biginelli reaction," Synlett, no. 1, pp. 67-70, 2003.

[28] Y. Ma, C. Qian, and M. Yang, "Lanthanide triflate catalyzed Biginelli reaction. One-pot synthesis of dihydropyrimidinones under solvent-free conditions," The Journal of Organic Chemistry, vol. 65, no. 12, pp. 3864-3868, 2000.

[29] S. A. Kotharkar, M. R. Jadhav, R. R. Nagawade, S. S. Bahekar, and D. B. Shinde, "Sulphamic acid $\left(\mathrm{H}_{2} \mathrm{NSO}_{3} \mathrm{H}\right)$ catalysed one pot synthesis of 3,4-dihydropyrimidin-2 $(1 \mathrm{H})$-ones and their thione analogues," Letters in Organic Chemistry, vol. 2, p. 662, 2005.

[30] M. M. Heravi, K. Bakhtiari, and F. F. Bamoharram, "12Molybdophosphoric acid: a recyclable catalyst for the synthesis of Biginelli-type 3,4-dihydropyrimidine-2(1H)-ones," Catalysis Communications, vol. 7, no. 6, pp. 373-376, 2006.

[31] M. Tajbakhsh, B. Mohajerani, M. M. Heravi, and A. N. Ahmadi, "Natural HEU type zeolite catalyzed Biginelli reaction for the synthesis of 3,4-dihydropyrimidin-2(1H) one derivatives," Journal of Molecular Catalysis A, vol. 236, no. 1-2, pp. 216-219, 2005.

[32] W. Su, J. Li, Z. Zheng, and Y. Shen, "One-pot synthesis of dihydropyrimidiones catalyzed by strontium(II) triflate under solvent-free conditions," Tetrahedron Letters, vol. 46, no. 36, pp. 6037-6040, 2005.

[33] R. Gupta and S. Paul, "Covalently anchored sulfonic acid onto silica as an efficient and recoverable interphase catalyst for the synthesis of 3,4-dihydropyrimidinones/thiones," Journal of Molecular Catalysis A, vol. 266, no. 1-2, pp. 50-54, 2006.

[34] F. Shirini, M. A. Zolfigol, and E. Mollarazi, " $\mathrm{ZrOCl}_{2}$. ${ }_{8} \mathrm{H}_{2} \mathrm{O}$ as an efficient reagent for the solvent-free synthesis of 3,4-dihydropyrimidin-2-(1H)-ones," Synthetic Communications, vol. 36, no. 16, pp. 2307-2310, 2006.

[35] F. Shirini, K. Marjani, and H. T. Nahzomi, "Silica triflate as an efficient catalyst for the solvent-free synthesis of 3,4dihydropyrimidin-2(1H)-ones," Arkivoc, vol. 2007, no. 1, pp. 51-57, 2007.

[36] F. Shirini, M. A. Zolfigol, and A. R. Abri, "Fe( $\left(\mathrm{HSO}_{4}\right)_{3}$ as an efficient catalyst for the preparation of 3,4-dihydropyrimidin$2(1 H)$-ones in solution and under solvent-free conditions," Journal of the Iranian Chemical Society, vol. 5, no. 1, pp. 96-99, 2008.

[37] F. Shirini, M. A. Zolfigol, and E. Mollarazi, "Solvent-free synthesis of 3,4-dihydropyrimidin-2(1H)-ones using trichloroisocyanuric acid," Letters in Organic Chemistry, vol. 2, no. 8, pp. 718-720, 2005.

[38] A. Debache, M. Amimour, A. Belfaitah, S. Rhouati, and B. Carboni, "A one-pot Biginelli synthesis of 3,4-dihydropyrimidin2 - $(1 H)$-ones/thiones catalyzed by triphenylphosphine as Lewis base," Tetrahedron Letters, vol. 49, no. 42, pp. 6119-6121, 2008.

[39] S. Chitra and K. Pandiarajan, "Calcium fluoride: an efficient and reusable catalyst for the synthesis of 3,4-dihydropyrimidin$2(1 H)$-ones and their corresponding $2(1 H)$ thione: an improved high yielding protocol for the Biginelli reaction," Tetrahedron Letters, vol. 50, no. 19, pp. 2222-2224, 2009.

[40] S. L. Jain, J. K. Joseph, and B. Sain, "Ionic liquid promoted an improved synthesis of 3,4-dihydropyrimidinones using [bmim] $\mathrm{BF}_{4}$ immobilized $\mathrm{Cu}$ (II) acetylacetonate as recyclable catalytic system," Catalysis Letters, vol. 115, no. 1-2, pp. 52-55, 2007.

[41] A. N. Dadhania, V. K. Patel, and D. K. Raval, "A convenient and efficient protocol for the one pot synthesis of 3,4-Dihydropyrimidin-2-(1H)-ones catalyzed by ionic liquids under ultrasound irradiation ", The Journal of the Brazilian Chemical Society, vol. 22, no. 3, p. 511, 2011.

[42] F. Shirini, M. A. Zolfigol, and J. Albadi, "Melamine trisulfonic acid: a new, efficient and recyclable catalyst for the synthesis of 3,4-dihydropyrimidin-2(1H)-ones/thiones in the absence of solvent," Chinese Chemical Letters, vol. 22, no. 3, pp. 318-321, 2011.

[43] H. Shi, W. Zhu, H. Li et al., "Microwave-accelerated esterification of salicylic acid using Brönsted acidic ionic liquids as catalysts," Catalysis Communications, vol. 11, no. 7, pp. 588-591, 2010.

[44] J. S. Wilkes, "Properties of ionic liquid solvents for catalysis," Journal of Molecular Catalysis A, vol. 214, no. 1, pp. 11-17, 2004.

[45] H. Wu, Y. Wan, X. M. Chen et al., "Synthesis of 2,4,5-triaryl-5Hchromeno[4,3-b]pyridines under microwave radiation," Journal of Heterocyclic Chemistry, vol. 46, no. 4, pp. 702-707, 2009. 

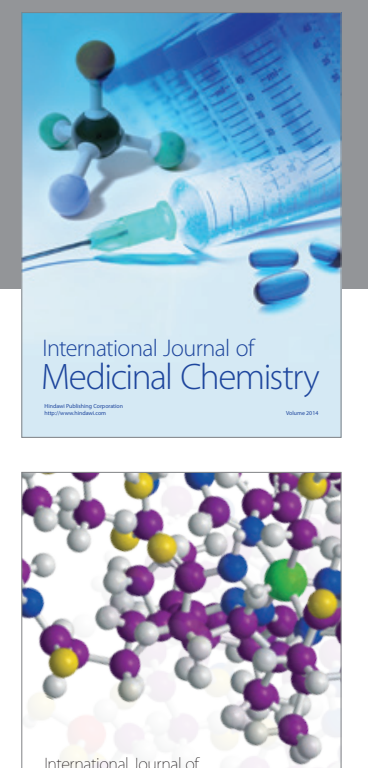

\section{Carbohydrate} Chemistry

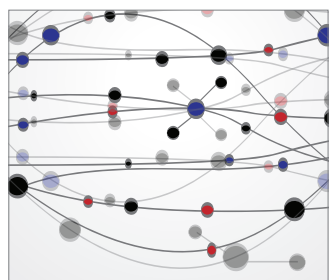

The Scientific World Journal
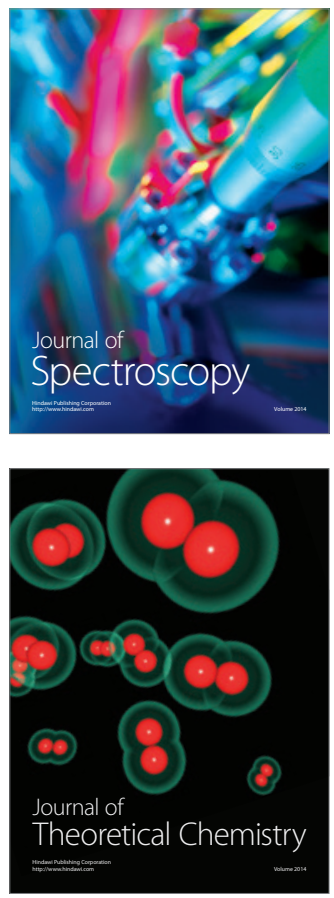
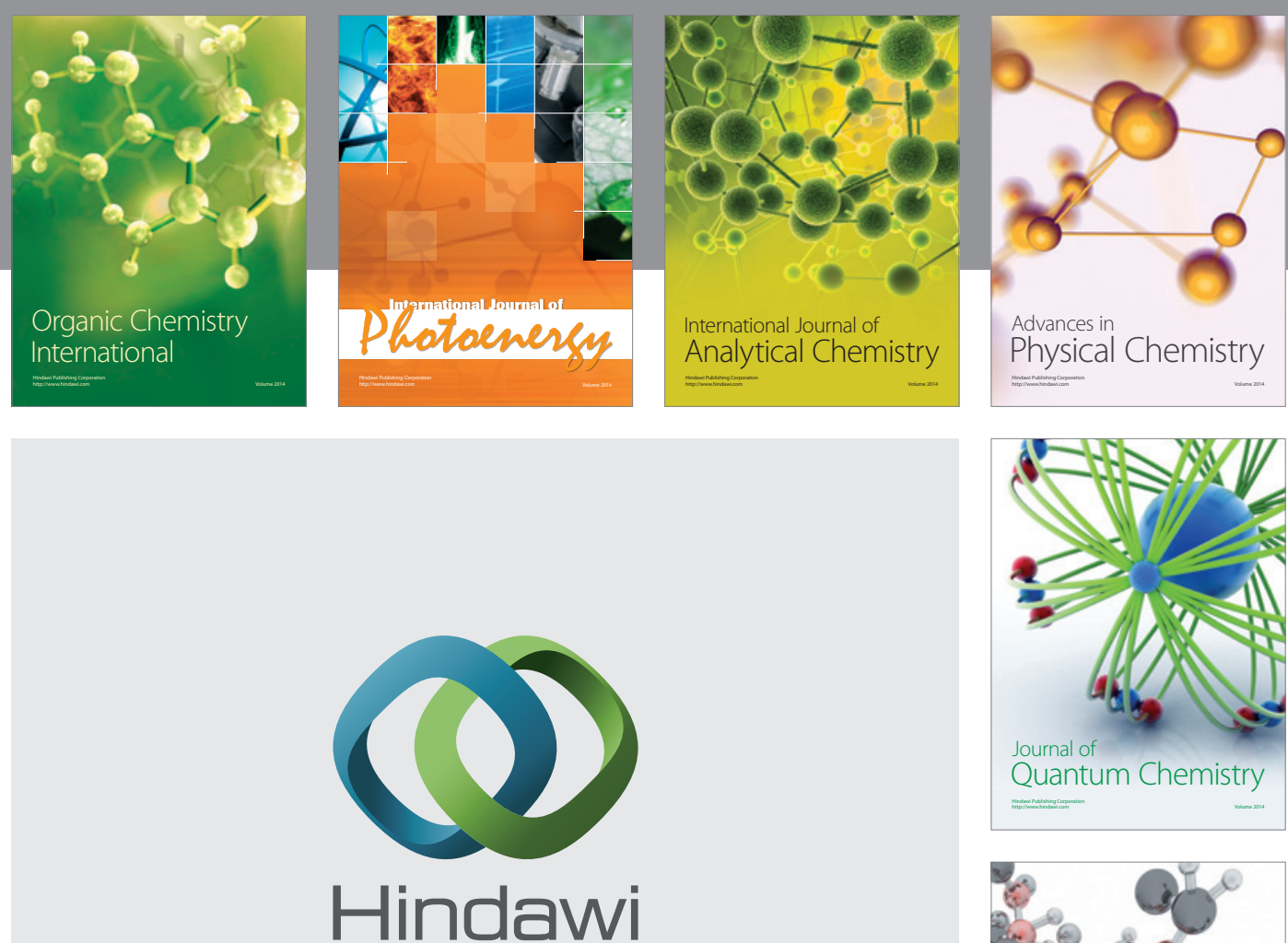

Submit your manuscripts at

http://www.hindawi.com

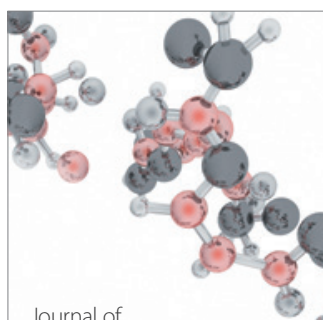

Analytical Methods

in Chemistry

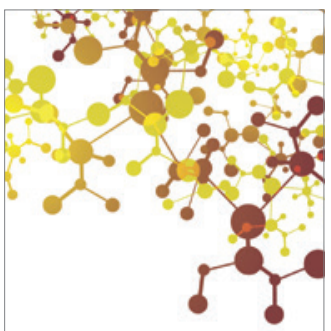

Journal of

Applied Chemistry

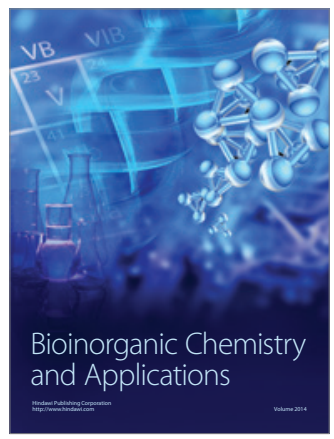

Inorganic Chemistry
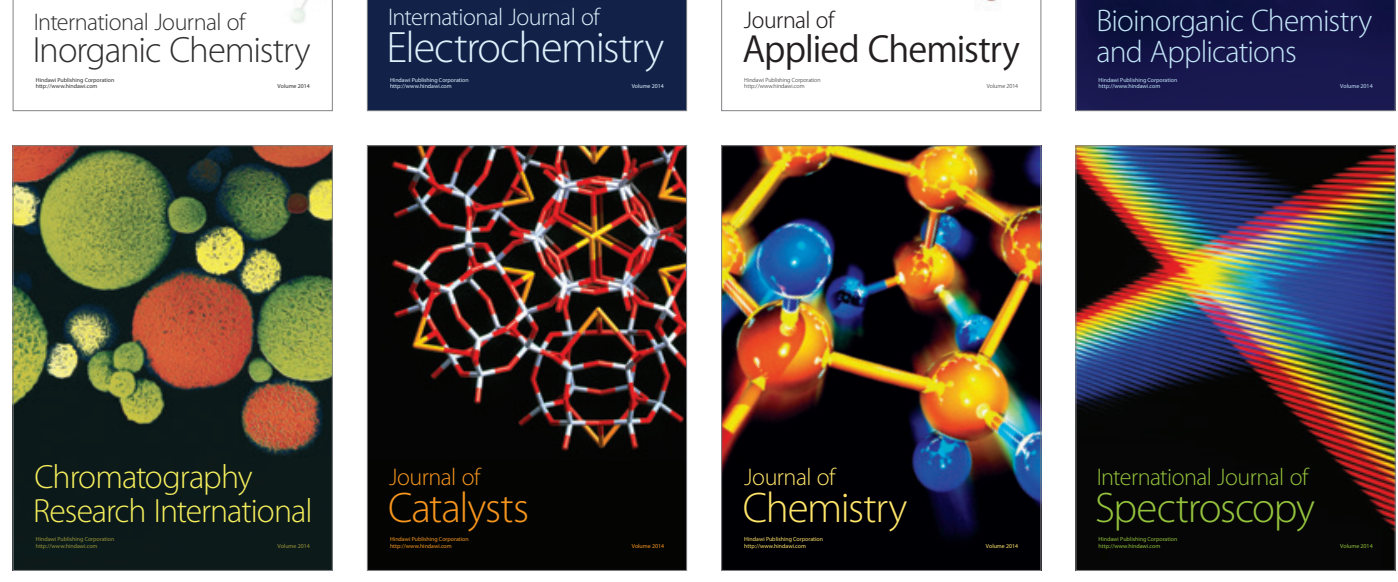